\title{
PENGUJIAN KUALITAS KAYU LAPIS UNTUK KONTRUKSI BANGUNAN YANG BEREDAR DI PASARAN KOTA BENGKALIS
}

\author{
Sonia Somadona ${ }^{1}$, Evi Sribudiani ${ }^{2}$, Tuti Arlita ${ }^{2}$ \\ ${ }^{1}$ Mahasiswa Fakultas Pertanian Universitas Riau \\ ${ }^{2}$ Staf Pengajar Fakultas Pertanian Universitas Riau \\ JIn. HR Subrantas Pekanbaru Riau \\ Email :sonia_hut@yahoo.co.id,sribudiani_unri@yahoo.co.id,arlita_unri@gmail.com
}

\begin{abstract}
Plywood is a composite product in form of an artificial board made of veneer sheets that were bonded together with an arrangement of perpendicular intersection. The quality of plywood circulating in Bengkalis City market was examined onits quality of the surface, inside and back space, moisture content and the thickness of its swell . The examination on the quality of plywood for construction of buildings circulating in Bengkalis City Market was using the standard of SNI 01-5008.2-1999. The test results of 4 plywood trademarks circulating in the market of Bengkalis City on its surface quality was showing that the product as known as Arwana and Tunas trademarks were belong to $C$ class, Fortune that has quality $B$ class, and OFR was on A class quality. While the quality inside of plywood of brand mark as Arwana, Tunas and Fortune were including to class $A$ quality (overlap defect), but those 2 natural and technical defects is not including to SNI requirement criterias (slit and length), OFR trademark plywood's inside quality was included into A classon its natural and technical defect criteria. Further, the quality of plywood's back space of those 4 trademarks circulating in Bengkalis City were included into the standard SNI 01-5008.2-1999. The examintaion of moisture content in accordance to SNI 015008.2-1999 standard showed that Fortune and OFR trademark were fulfilling the requirement standard of $14 \%$, while Arwana and Tunas were having higher water content $(\geq 20 \%)$. At last, the thickness swell of all trademarks were in conformity with the SNI 01-5008.2-1999, in which reqiuring its thickness of 12\%.
\end{abstract}

Keywords: quality, plywood, Bengkalis

\section{PENDAHULUAN}

Ketersediaan kayu solid berkualitas di Indonesia dari tahun ke tahun semakin berkurang dan harganya semakin mahal. Hal ini sebagai akibat peningkatan kebutuhan masyarakat akan kayu. Menurut Food Agriculture Organization (FAO), angka deforestasi
Indonesia tahun 2000-2005 mencapai 1,8 juta hektar/tahun. Angka ini lebih rendah bila dibandingkan dengan angka resmi yang dikeluarkan oleh Departemen Kehutanan (2005) yaitu 2,8 juta hektar/tahun.

Untuk menanggulangi masalah tersebut, saat ini penggunaan kayu solid 
sudah beralih kepenggunaan produk komposit salah satunya adalah kayu lapis. Kayu lapis adalah produk komposit yang berupa papan tiruan yang terbuat dari lembaran-lembaran vinir yang direkat bersama dengan susunan bersilangan tegak lurus (Haygreen and Bowyer, 1993). Kayu lapis sendiri memiliki kelebihan antara lain adalah memiliki berat yang ringan dibandingkan luas permukaannya, bidang yang luas dapat ditutup dalam waktu singkat, dapat dibuat menurut ukuran yang dikehendaki, serta warna, tekstur dan pola serat dapat diseragamkan sehingga corak/pola bisa simetris. Kayu lapis pada saat ini banyak digunakan sebagai bahan bagunan untuk dinding, asbes, pintu, dan lainlain. Berdasarkan kelebihan-kelebihan dari kayu lapis tersebut, produk ini banyak beredar dipasaran dan cukup disukai oleh konsumen untuk pengganti penggunaan kayu solid termasuk masyarakat yang berada di daerah pesisir yaitu Kota Bengkalis.

Kota Bengkalis beriklim tropis yang sangat dipengaruhi oleh sifat iklim laut dengan temperatur berkisar $26^{\circ} \mathrm{C}$ $32^{\circ} \mathrm{C}$ dan kelembaban $85 \%$. Kondisi iklim di Kota Bengkalis juga dipengaruhi oleh angin, yaitu angin utara, timur, barat dan angin selatan. Serta kondisi substrat yang terdiri dari pasir lumpur sehingga kontruksi bangunan yang ada di Kota Bengkalis berbeda dari daerah lain. Sehingga ketika masyarakat Bengkalis memilih kayu lapis yang akan mereka gunakan sebagai bahan bangunan harus memilih kayu lapis dengan kualitas yang baik, akan tetapi masyarakat biasanya memilih kayu lapis sebagai bahan baku bangunan hanya berdasarkan harga dan dimensi saja tanpa mengetahui kualitas dari kayu lapis tersebut karena penampakan kayu lapis dari berbagai merek dagang tersebut memiliki penampakan visual yang hampir sama.

Melihat hal tersebut diatas maka perlunya dilakukan penelitian yang berjudul "Pengujian Kualitas Kayu Lapis Untuk Kontruksi Bangunan Yang Beredar Di Pasaran Kota Bengkalis" sehingga masyarakat dapat mempertimbangkan pemilihan merek dagang kayu lapis apayang sesuai untuk dijadikan bahan kontruksi bangunan di Kota Bengkalis.

Penelitian ini bertujuan untuk mengetahui kualitas dari kayu lapis yang beredar dipasaran Kota Bengkalis, serta memberikan informasi kepada masyarakat mengenai kualitas dari dari 
masing-masing kayu lapis dengan berbagai merek dagang sehingga masyarakat dapat memilih atau menggunakan kayu lapis dengan kualitas yang baik.

\section{METODE PENELITIAN}

Penelitian ini dilaksanakan di Laboratorium Kehutanan Fakultas Pertanian Universitas Riau. Bahan yang

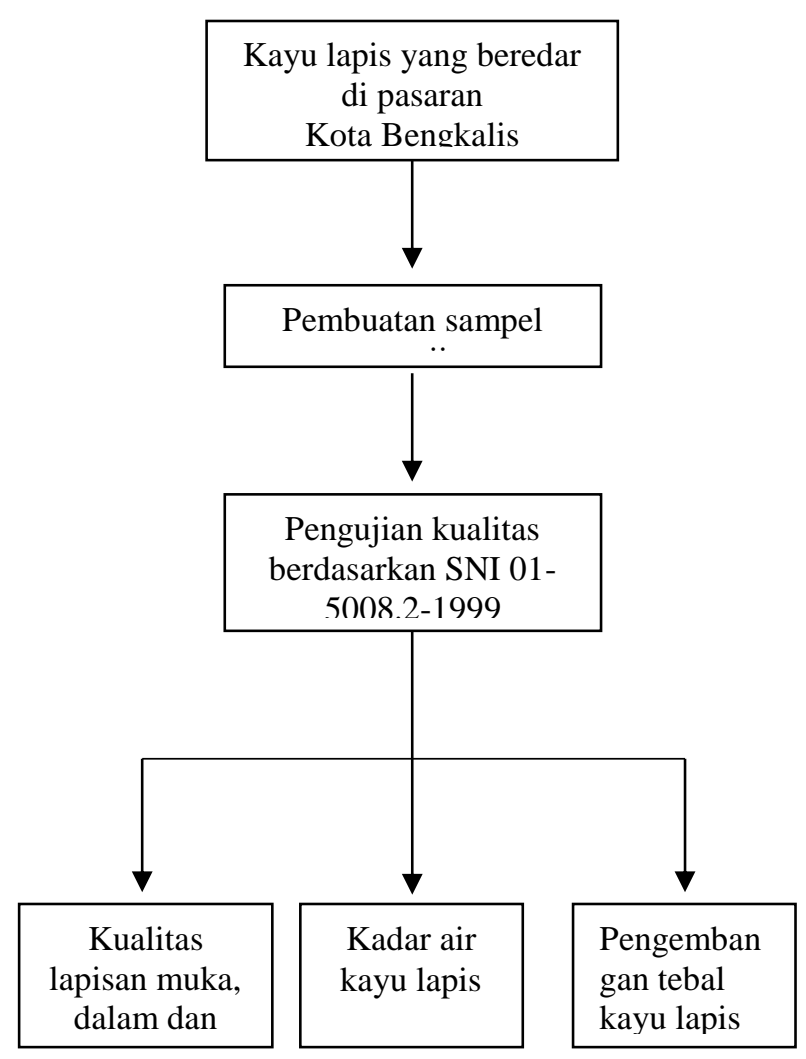

Gambar 1. Alur Tahapan Penelitian.

HASIL DAN PEMBAHASAN

Survey kayu lapis dipasaran Kota Bengkalis

Hasil survey kayu lapis di pasaran Kota Bengkalis di dapat bahwa digunakan dalam penelitian ini adalah kayu lapis yang beredar di pasaran Kota Bengkalis. Kemudian Alat yang digunakan adalah jangka sorong, timbangan analitik, gergaji, penggaris/meteran, kaca pembesar, oven. Adapun alur tahapan dari penelitian ini dapat dilihat pada gambar 1 di bawah ini.

ada 4 merek dagang yang beredar di pasaran dengan berbagai ukuran ketebalan.Dari hasil survey diketahui kayu lapis dari 4 merek dagang tersebut di dominasi dengan ketebalan $\pm 3 \mathrm{~mm}$ sehingga pada penelitian ini digunakan kayu lapis dengan ketebalan tersebut. Berikut gambar toko bangunan yang ada di Kota Bengkalis :

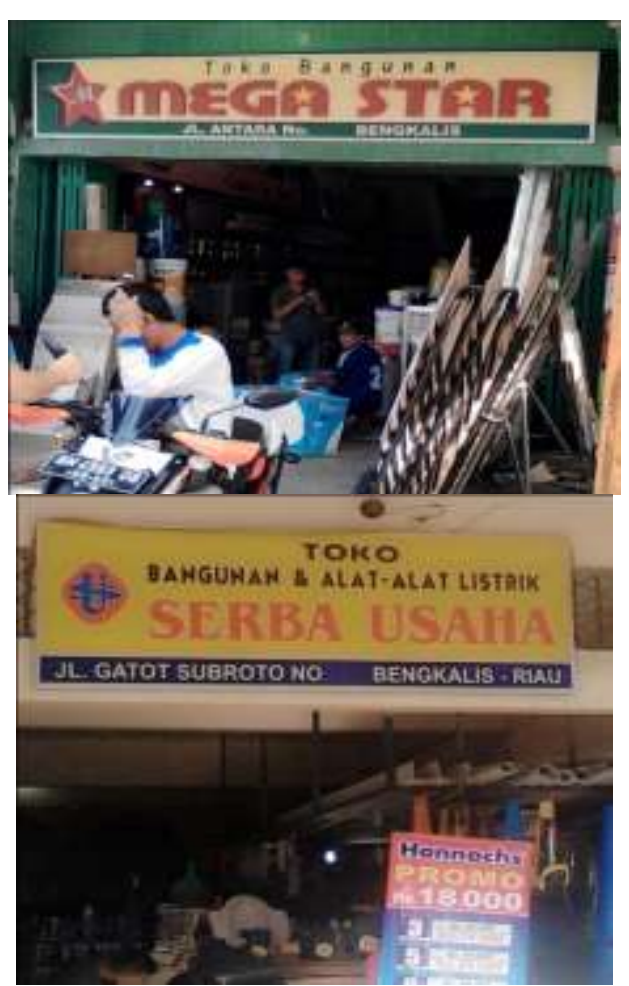


Gambar 2. Toko Bahan Bangunan di Kota Bengkalis

Pengujian kualitas lapisan muka, kayu lapis dapat dilihatpada tabel 1 dalam, dan belakang Kayu lapis dibawah ini

Hasil pengujian kualitas muka

\section{Tabel 1. Hasil pengujian kualitas muka kayu lapis}

\begin{tabular}{|c|c|c|c|c|c|}
\hline \multirow[t]{2}{*}{$\begin{array}{l}\text { Merek } \\
\text { Dagang }\end{array}$} & \multirow[t]{2}{*}{$\begin{array}{l}\text { Cacat Alami } \\
\text { dan Teknis }\end{array}$} & \multicolumn{3}{|c|}{ Ulangan } & \multirow[t]{2}{*}{ Mutu } \\
\hline & & 1 & 2 & 3 & \\
\hline \multirow[t]{7}{*}{ Arwana } & $\begin{array}{l}\text { Mata kayu } \\
\text { sehat } \\
\text { Mata kayu } \\
\text { busuk }\end{array}$ & $\begin{array}{l}\varnothing 2-4 \mathrm{~mm}, 10 \text { buah, } \\
\text { tersebar } \\
\varnothing 15-35 \mathrm{~mm}, 4 \\
\text { buah }\end{array}$ & $\begin{array}{l}\varnothing 2-15 \mathrm{~mm}, \\
48 \text { buah, } \\
\text { tersebar } \\
\varnothing 9-10 \mathrm{~mm}, 2 \\
\text { buah }\end{array}$ & $\begin{array}{l}\varnothing 2-50 \mathrm{~mm}, 47 \text { buah, } \\
\text { tersebar } \\
\varnothing 10-11 \mathrm{~mm}, 2 \text { buah }\end{array}$ & C \\
\hline & Gerek bulat & $\varnothing<1 \mathrm{~mm}, 7$ buah & - & $\varnothing<1 \mathrm{~mm}, 3$ buah & $A$ \\
\hline & $\begin{array}{l}\text { Pecah } \\
\text { Retak }\end{array}$ & $\begin{array}{l}\text { buah, diamplas rata } \\
\text { Panjang } 160 \mathrm{~mm} \text {, }\end{array}$ & - & - & $A$ \\
\hline & Melintang & $\begin{array}{l}\text { seperti rambut } \\
\text { tidak mencolok, } \\
\text { didempul dan } \\
\text { diamplas rata }\end{array}$ & $\begin{array}{l}\text { - } \\
\text { tidak } \\
\text { mencolok, } \\
\text { didempul dan } \\
\text { diamplas rata }\end{array}$ & $\begin{array}{l}\text { sedikit, didempul dan } \\
\text { diamplas rata }\end{array}$ & C \\
\hline & rata & $\begin{array}{l}2 \text { buah } \\
\text { Diperbaiki, halus }\end{array}$ & 3 buah & - & - \\
\hline & Goresan & dan rata & - & - & $\mathrm{C}$ \\
\hline & Cacat pisau & $1-10 \mathrm{~mm}$ & $2 \mathrm{~mm}$ & - & - \\
\hline \multirow[t]{9}{*}{ Tunas } & $\begin{array}{l}\text { Mata kayu } \\
\text { sehat }\end{array}$ & $\begin{array}{l}\varnothing 2-90 \mathrm{~mm}, 32 \\
\text { buah, tersebar }\end{array}$ & $\begin{array}{l}\varnothing 2-19 \mathrm{~mm}, 5 \\
\text { buah, tersebar } \\
\varnothing 6-31 \mathrm{~mm}, 3\end{array}$ & $\begin{array}{l}\varnothing 3-28 \mathrm{~mm}, 8 \text { buah, } \\
\text { tersebar }\end{array}$ & $\mathrm{C}$ \\
\hline & $\begin{array}{l}\text { Mata kayu } \\
\text { busuk }\end{array}$ & $\varnothing 5-34 \mathrm{~mm}, 3$ buah & $\begin{array}{l}\text { buah, di } \\
\text { dempul } \\
\varnothing 1 \mathrm{~mm}, 1\end{array}$ & Ø 5 -34 mm, 3 buah & - \\
\hline & Gerek bulat & - & $\begin{array}{l}\text { buah } \\
\leq 2 \times 196 \mathrm{~mm}\end{array}$ & - & $A$ \\
\hline & $\begin{array}{l}\text { Pecah } \\
\text { Retak }\end{array}$ & $\begin{array}{l}\leq 2 \times 30 \mathrm{~mm}, 2 \\
\text { buah, diamplas rata }\end{array}$ & $\begin{array}{l}5 \text { buah, } \\
\text { diamplas rata } \\
\text { Panjang } 649\end{array}$ & $\begin{array}{l}\leq 3 \times 197 \mathrm{~mm}, 3 \\
\text { buah, diamplas rata } \\
\text { Panjang } 102 \mathrm{~mm}\end{array}$ & $A$ \\
\hline & Melintang & Panjang 94 mm & $\begin{array}{l}\text { mm, panjang } \\
\text { tidak } \\
\text { mencolok, }\end{array}$ & seperti rambut & - \\
\hline & $\begin{array}{l}\text { Cacat kempa } \\
\text { Ketebalan tidak }\end{array}$ & $\begin{array}{l}\text { Sedikit, didempul } \\
\text { dan diamplas rata }\end{array}$ & $\begin{array}{l}\text { didempul dan } \\
\text { diamplas rata }\end{array}$ & Mencolok & C \\
\hline & $\begin{array}{l}\text { rata } \\
\text { Noda perekat }\end{array}$ & 1 buah & 1 buah & 1 buah & - \\
\hline & kertas & - & Sedikit & - & C \\
\hline & Lapuk & Sedikit & - & - & $\mathrm{C}$ \\
\hline Fortune & $\begin{array}{l}\text { Mata kayu } \\
\text { sehat }\end{array}$ & $\begin{array}{l}\varnothing 2-12 \mathrm{~mm}, 8 \\
\text { buah, tersebar }\end{array}$ & $\begin{array}{l}\varnothing 2-19 \mathrm{~mm}, 5 \\
\text { buah, tersebar }\end{array}$ & $\begin{array}{l}\varnothing 3-28 \mathrm{~mm}, 8 \text { buah, } \\
\text { tersebar }\end{array}$ & $\mathrm{B}$ \\
\hline
\end{tabular}




\begin{tabular}{|c|c|c|c|c|c|}
\hline \multirow[t]{2}{*}{$\begin{array}{l}\text { Merek } \\
\text { Dagang }\end{array}$} & \multirow[t]{2}{*}{$\begin{array}{l}\text { Cacat Alami } \\
\text { dan Teknis }\end{array}$} & \multicolumn{3}{|c|}{ Ulangan } & \multirow[t]{2}{*}{ Mutu } \\
\hline & & 1 & 2 & 3 & \\
\hline \multirow{13}{*}{ OFR } & $\begin{array}{l}\text { Mata kayu } \\
\text { busuk }\end{array}$ & - & $\begin{array}{l}\varnothing 2-7 \mathrm{~mm}, 6 \\
\text { buah, di } \\
\text { dempul } \\
\varnothing 1 \mathrm{~mm}, 26\end{array}$ & Ø $3-5$ mm, 2 buah & B \\
\hline & Gerek bulat & - & $\begin{array}{l}\text { buah } \\
\leq 5 \times 286 \mathrm{~mm}\end{array}$ & $\varnothing 1 \mathrm{~mm}, 26$ buah & C \\
\hline & $\begin{array}{l}\text { Pecah } \\
\text { Retak }\end{array}$ & $\begin{array}{l}\leq 2 \times 332 \mathrm{~mm}, 2 \\
\text { buah, diamplas rata }\end{array}$ & $\begin{array}{l}4 \text { buah, } \\
\text { diamplas rata } \\
\text { Panjang } \leq 136\end{array}$ & $\begin{array}{l}\leq 2 \times 382 \mathrm{~mm}, 5 \\
\text { buah, diamplas rata }\end{array}$ & B \\
\hline & Cacat kempa & Panjang $\leq 298$ mm & $\begin{array}{l}\text { mm } \\
\text { sedikit, } \\
\text { didempul dan } \\
\text { diamplas rata } \\
\text { panjang } 46 \mathrm{x}\end{array}$ & $\begin{array}{l}\text { sedikit, didempul dan } \\
\text { diamplas rata }\end{array}$ & B \\
\hline & Sisipan & - & $341 \mathrm{~mm}$ & - & $\mathrm{C}$ \\
\hline & $\begin{array}{l}\text { Mata kayu } \\
\text { sehat } \\
\text { Mata kayu }\end{array}$ & $\begin{array}{l}\varnothing 2 \text {-90 mm, } 22 \\
\text { buah, tersebar }\end{array}$ & - & $\begin{array}{l}\varnothing 1-25 \mathrm{~mm}, 20 \text { buah, } \\
\text { tersebar }\end{array}$ & C \\
\hline & busuk & $\varnothing \leq 13 \mathrm{~mm}, 1$ buah & - & - & B \\
\hline & Gerek bulat & $\varnothing 1 \mathrm{~mm}, 1$ buah & buah & - & A \\
\hline & $\begin{array}{l}\text { Pecah } \\
\text { Retak }\end{array}$ & $\begin{array}{l}\leq 2 \times 8 \mathrm{~mm}, 1 \text { buah, } \\
\text { diamplas rata }\end{array}$ & $\begin{array}{l}\text { buah, } \\
\text { diamplas rata } \\
\text { Panjang } \leq 207\end{array}$ & $\begin{array}{l}\leq 3 \times 197 \mathrm{~mm}, 3 \\
\text { buah, diamplas rata } \\
\text { Panjang } \leq 89 \mathrm{~mm}\end{array}$ & A \\
\hline & Melintang & - & $\mathrm{mm}$ & seperti rambut & C \\
\hline & Cacat kempa & $\begin{array}{l}\text { Sedikit, didempul } \\
\text { dan diamplas rata }\end{array}$ & - & $\begin{array}{l}\text { Sedikit, didempul dan } \\
\text { diamplas rata }\end{array}$ & B \\
\hline & Cacat pisau & $\leq 6 \mathrm{~mm}$ & - & - & - \\
\hline & Sisipan & - & $\begin{array}{l}\text { Panjang } 3 \times 10 \\
\text { mm }\end{array}$ & - & $\mathrm{B}$ \\
\hline
\end{tabular}

Hasil pengujian kualitas muka kayu lapis dengan merek masingmasing merek dagang yang beredar di Kota Bengkalis menunjukan ada beberapa cacat alami dan cacat teknik yang tidak masuk kedalam kelas mutu baik A, B maupun $\mathrm{C}$ terutama pada retak melintang, ketebalan tidak rata serta cacat pisau. Hal ini dikarenakan kualitas dari bahan baku yang digunakan rendah serta proses pengerjaan yang kurang baik. Akan tetapi jika dilihat dari cacat lainnya dapat diketahui bahwa kayu lapis dari 4 jenis merek sudah memiliki kualitas mutu SNI terutama mutu B, tetapi yang mempunyai kualiatas yang baikdengan merek dagang OFR dimana setiap cacat alami dan teknis yang terdapat termasuk kedalam mutu $B$ dan $A$ dengan rata-rata termasuk kedalam mutu B. Melihat kualitas muka kayu lapis ini dapat dikatakan ketika digunakan sebagai bahan baku kontruksi bangunan akan menunjukan nilai dekoratif yang kurang indah, karena banyak terdapat cacatalami dan teknis (mutu $\mathrm{C}$ ), sehingga ketika dijadikan pelapislantai, atap dan 
dinding rumah akan kelihatan cacatcacatyang ada di kayu lapis tersebut. Sealian itu dikarenakan kayu lapis pada masing-masing merek dagang terdapat mata kayu, pecah yang besar serta retak memanjang, kayu lapis ini tidak cocok untuk kontruksi banguanan terutama penggunaan sebagai pelapis lantai, atap dan dinding, sehingga ketika diberi gaya tekanan sejajar bidang panilnya kayu lapis tersebut akan rusak dan tidak bisa menahan gaya yang diberikan. Kemudian jika kayu lapis memiliki kualitas muka yang baik (sesuai standard) maka kayu lapis ini dapat tahan terhadap angin rebut dan gempa. Hal ini sesuai dengan Haygreen and Bowyer(1993) yang menyatakan keuntungan kayu lapis pada persegi panjangnya yang keras dan kaku yang membuat hampir mustahil untuk diubah bentuknya oleg gaya sejajar bidang panilnya. Inilah sebabnya jika kayu lapis digunakan sebagai pelapi lantai, atap dan dinding luar, struktur tersebut luar biasa kuatnya dan tahan terhadap angin rebut dan gempa. Dari hasil pengujian kualitas dalam kayu lapis dapat dilihat pada tabel 2 berikut

Tabel 2. Hasil pengujian kualitas dalam kayu lapis

\begin{tabular}{|c|c|c|c|c|c|}
\hline \multirow[t]{2}{*}{$\begin{array}{l}\text { Merek } \\
\text { Dagang }\end{array}$} & \multirow[t]{2}{*}{$\begin{array}{l}\text { Cacat Alami dan } \\
\text { Teknis }\end{array}$} & \multicolumn{3}{|c|}{ Ulangan } & \multirow[t]{2}{*}{ Mutu } \\
\hline & & & & 2 & \\
\hline \multirow[t]{3}{*}{ Arwana } & Tumpang tindih & - & - & - & $A$ \\
\hline & Celah & $\begin{array}{l}\leq 43,4 \mathrm{~mm} \\
\leq 12,8 \mathrm{~mm}, 3\end{array}$ & $\begin{array}{l}\leq 37,6 \mathrm{~mm} \\
\leq 12,3 \mathrm{~mm}, 1\end{array}$ & $\leq 26,3 \mathrm{~mm}$ & - \\
\hline & Ukuran panjang & buah & buah & - & - \\
\hline \multirow[t]{3}{*}{ Tunas } & Tumpang tindih & - & - & - & A \\
\hline & Celah & $\begin{array}{l}- \\
\leq 12,4 \mathrm{~mm}, 6\end{array}$ & $\leq 36,2 \mathrm{~mm}$ & $\leq 50,3 \mathrm{~mm}$ & - \\
\hline & Ukuran panjang & buah & - & $\leq 36 \mathrm{~mm}, 4$ buah & - \\
\hline \multirow[t]{2}{*}{ Fortune } & Tumpang tindih & - & - & - & A \\
\hline & $\begin{array}{l}\text { Celah } \\
\text { Ukuran panjang }\end{array}$ & $\begin{array}{l}\leq 18,1 \mathrm{~mm} \\
\leq 31 \mathrm{~mm}, 5 \\
\text { buah }\end{array}$ & $\begin{array}{l}\leq 51,4 \mathrm{~mm} \\
\leq 30,3 \mathrm{~mm}, 6 \\
\text { buah }\end{array}$ & $\begin{array}{l}\leq 29,2 \mathrm{~mm} \\
\leq 50,7 \mathrm{~mm}, 7 \\
\text { buah }\end{array}$ & - \\
\hline \multirow[t]{3}{*}{ OFR } & Tumpang tindih & - & - & - & $A$ \\
\hline & Celah & - & - & - & $A$ \\
\hline & Ukuran panjang & - & - & - & A \\
\hline
\end{tabular}

Hasil pengujian menunjukan bahwa Arwana, Tunas dan Fortune, tidak kayu lapis dengan merek dagang masuk kedalam kriteria SNI pada 
bangian celah dan ukuran panjang, tersebut, Karena jika diberikan sedangkan OFR masuk kedalam SNI dengan kelas mutu A. Rendahnya mutu pada bagian dalam sering kali terjadi, karena produsen menganggap itu tidak penting, dikarenakan bagian dalam, serta konsumen juga tidak dapat melihat dengan langsung, akan tetapi kualitas bagian dalam sangat berpengaruh pada kekuatan, jika terlalu banyak tumpang tindih vinir, celah dan ukuran panjang yang tidak sesuai , maka akan menurunkan kualitas dari kayu lapis pembebanan yang terus menerus bagian yang terdapat celah dan ukuran panjang yang tidak sama akan mengalami perlemahan kekuatan. Hal ini sesuai dengan pernyataaan Haygreen and Bowyer (1993) yang menyatakan kualitas/kekuatan bagian dalam harus lebih bagus dibandingkan bagian luar untuk kayu lapis struktural. Dari hasil pengujian kualitas belakang kayu lapis dapat dilihat pada tabel 3 dibawah ini :

Tabel 3. Hasil pengujian kualitas belakang kayu lapis

\begin{tabular}{|c|c|c|c|c|c|}
\hline \multirow[t]{2}{*}{$\begin{array}{l}\text { Merek } \\
\text { Dagang }\end{array}$} & \multirow[t]{2}{*}{$\begin{array}{l}\text { Cacat Alami } \\
\text { dan Teknis }\end{array}$} & \multicolumn{3}{|c|}{ Ulangan } & \multirow[t]{2}{*}{ Mutu } \\
\hline & & 1 & 2 & 3 & \\
\hline \multirow[t]{11}{*}{ Arwana } & $\begin{array}{l}\text { Mata kayu } \\
\text { sehat } \\
\text { Mata kayu }\end{array}$ & 23 buah & 29 buah & 58 buah & $\mathrm{SNI}$ \\
\hline & & - & 4 buah & 5 buah & SNI \\
\hline & $\begin{array}{l}\text { Gerek bulat } \\
\text { Gerek }\end{array}$ & 4 buah & 2 buah & - & $\mathrm{SNI}$ \\
\hline & panjang & $\begin{array}{l}1 \text { buah } \\
\leq 0,2 \times 28 \mathrm{~mm}, 9 \\
\text { buah, diamplas }\end{array}$ & $\begin{array}{l}- \\
\leq 0,3 \times 4,7 \mathrm{~mm}, \\
1 \text { buah, }\end{array}$ & - & $\mathrm{SNI}$ \\
\hline & & rata & & $\begin{array}{l}\leq 0,4 \times 2,6 \mathrm{~mm} \\
\text { tidak mencolok, }\end{array}$ & SNI \\
\hline & $\begin{array}{l}\text { Cacat } \\
\text { kempa } \\
\text { Ketebalan }\end{array}$ & - & $\begin{array}{l}\text { didempul dan } \\
\text { diamplas rata }\end{array}$ & $\begin{array}{l}\text { didempul dan } \\
\text { diamplas rata } \\
\text { melembung. }\end{array}$ & SNI \\
\hline & tidak rata & $\begin{array}{l}3 \text { buah } \\
\text { tidak mencolok, }\end{array}$ & tampak jelas & tampak jelas & SNI \\
\hline & Goresan & halus dan rata & - & - & SNI \\
\hline & $\begin{array}{l}\text { Cacat pisau } \\
\text { Noda }\end{array}$ & - & tidak mencolok & - & SNI \\
\hline & perekat & tidak mencolok & tidak mencolok & tidak mencolok & SNI \\
\hline & Sisipan & 3 buah & - & - & SNI \\
\hline \multirow[t]{2}{*}{ Tunas } & $\begin{array}{l}\text { Mata kayu } \\
\text { sehat } \\
\text { Mata kayu }\end{array}$ & 28 buah & 30 buah & 40 buah & SNI \\
\hline & busuk & 5 buah & 3 buah & 12 buah & SNI \\
\hline
\end{tabular}




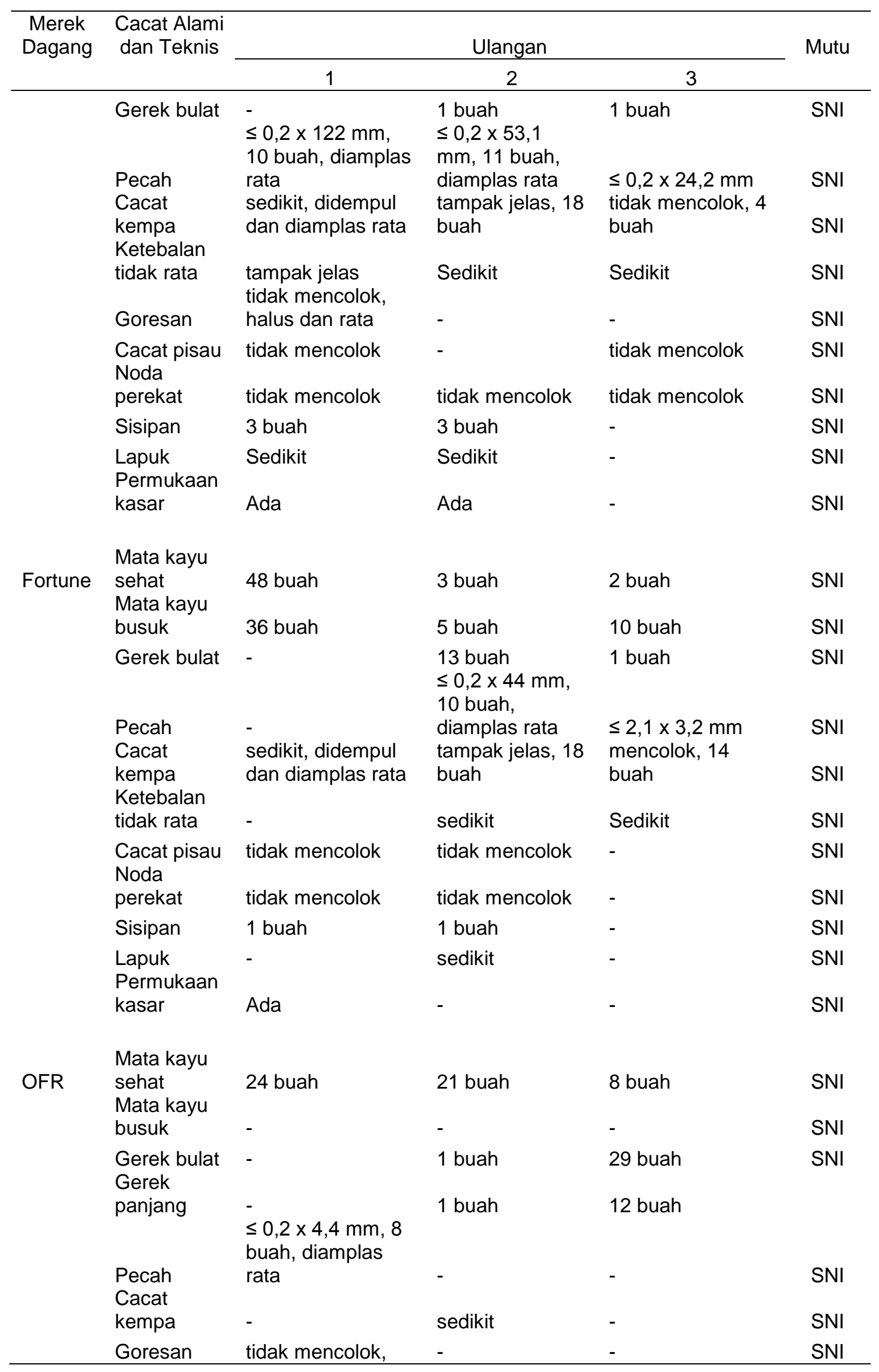




\begin{tabular}{|c|c|c|c|c|c|}
\hline \multirow[t]{2}{*}{$\begin{array}{c}\text { Merek } \\
\text { Dagang }\end{array}$} & \multirow[t]{2}{*}{$\begin{array}{l}\text { Cacat Alami } \\
\text { dan Teknis }\end{array}$} & \multicolumn{3}{|c|}{ Ulangan } & \multirow[t]{2}{*}{ Mutu } \\
\hline & & 1 & 2 & 3 & \\
\hline & & \multicolumn{3}{|c|}{ halus dan rata } & \\
\hline & \multirow{3}{*}{$\begin{array}{l}\text { Sisipan } \\
\text { Permukaan } \\
\text { kasar } \\
\text { Perubahan } \\
\text { warna }\end{array}$} & 1 buah & - & 4 buah & SNI \\
\hline & & Ada & & - & SNI \\
\hline & & - & \multirow{2}{*}{ ada } & Ada & SNI \\
\hline & Sambungan & - & & 1 buah & SNI \\
\hline
\end{tabular}

Hasil pengujian kualitas lapisan belakang kayu lapis dengan masingmasing merek dagang yang beredar di Kota Bengkalis menunjukan bahwa kayu lapis pada bagian belakang sudah sesuai dengan standard yang di tetapkan SNI 01-5008.2-1999 dikarekan lapisan belakang kayu lapis tidak memiliki kriteria mutu $A, B, C$ dan $D$ hanya masuk kriteria atau tidak. Lapisan belakang sering kali vinir yang digunakan memiliki kualitas rendah, dikarenakan penggunaannya di bagian sebelah dalamdan tidak tampak dari
luar.Sehingga ketika digunakan sebagai pelapis lantai, atap dan dinding tidak mempengaruhi keindahanya. Oleh karena itu untuk tidak ada pengaruhnya kualitas bagian belakang kayu lapis ini jika digunakan sebagai bahan kontruksi bangunan di Kota Bengkalis, hal ini dpat dilihat dari SNI 01-5008.2-1999 yang tidak menentukan mutu bagian belakang kayu lapis secara spesifik.

\section{Pengujian Kadar air}

Hasil pengujian kadar air pada 4 merek dagang kayu lapis didapat hasil sebagai berikut :

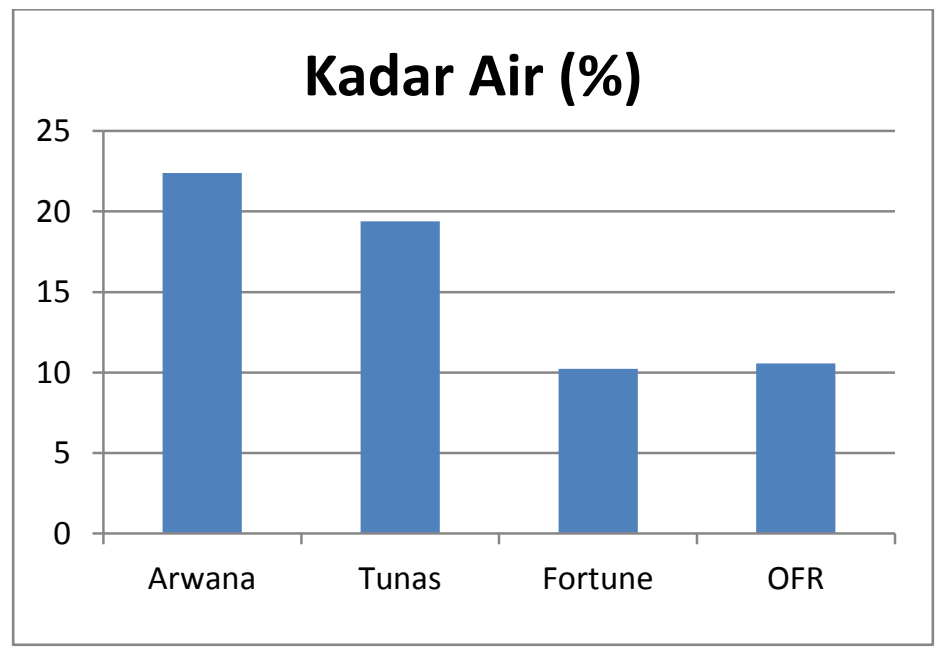

Gambar 3. Kadar air Kayu lapis 
Hasil pengujian menunjukan bahwa yang digunakan sebagai bahan baku masing-masing kayu lapis yang ada di pasaran Kota Bengkalis memiliki kadar air yang berbeda-beda, dimana kadar air tertinggi pada kayu lapis dengan merek dagang Arwana sedangkan terkecil pada merek dagang Fortune.Perbedaan kadar air kayu lapis diduga dikarenakan kadar air awal vinir yang digunakan. Berdasarkan SNI 01-5008.2-1999 kadar air kayu lapis yang beredar dipasaran Kota Bengkalis yang masuk kedalam standard penggunaan umum adalah merek dagang Fortune dan OFR dimana kadar air yang ditetapkan SNI 015008.2-1999 tidak boleh lebih dari 14\%.Tingginya kadar air pada kayu lapis akan mempengaruhi kualitas kayu lapis kontruksi bangunan di Kota bengkalis dimana diketahui kelembaban disana tinggi yaitu $85 \%$ dan juga dipengaruhi oleh angin sehingga ketika kayu lapis dengan kadar air tinggi digunakan untuk kontruksi bangunan, kayu lapis tersebut akan cepat rusak atau terbuka lapisannya serta akan mudah berubah dimensinya (ukuran) yang disebabkan kayu yang memiliki sifat higrokopis (Haygreen and Bowyer, 1993).

\section{Pengembangan tebal}

Hasil pengujian pengembangan tebal 2 jam dan 24 jam air pada 4 merek dagang kayu lapis didapat hasil sebagai berikut :

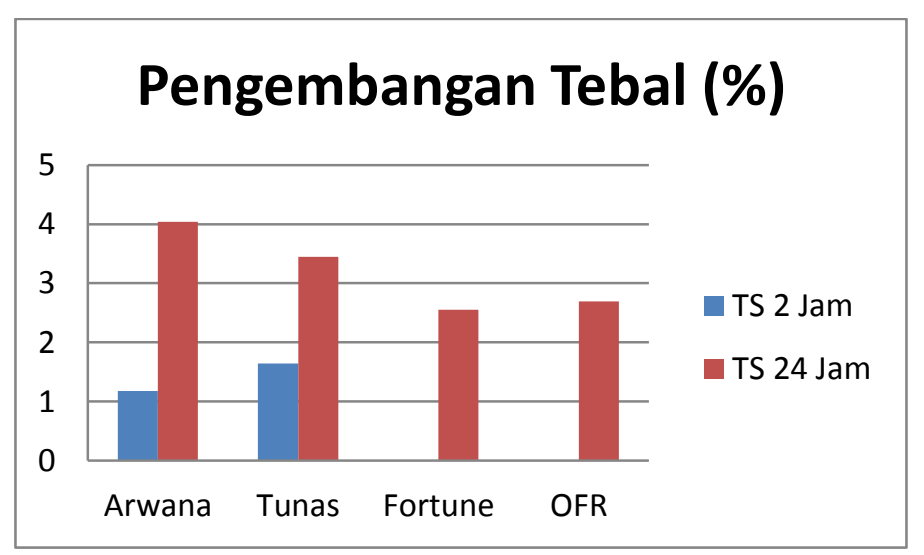

Gambar 4. Pengembangan Tebal 2 Jam dan 24 Jam Kayu lapis

Pengembangan tebal kayu lapis kemampuan papan menjaga stabilitas merupakan sifat fisis untuk mengukur dimensinya selama direndam dalam air. 
Semakin tinggi nilai pengembangan tebal maka semakin rendah kestabilan dimensinya, demikian juga sebaliknnya. Pengembangan tebal tertinggi pada kayu lapis merek arwana dan terendah adalah fortune. Besarnya peng embangan tebal pada 2 jam dan 24 jam dipengaruhi oleh jenis perekat yang digunakan dimana terjadi kerusakan pada ikatan perekat tersebut, semakin tahan perekat terhadap air semakin kecil pengembangan tebal. Hal ini sesuai dengan pernyataan Syamani, dkk (2008) bahwa terjadinya pengembangan tebal panel merupakan kombinasi dari potensi thickness recovery dari partikel yang didensifikasi dan kerusakan dari jaringanikatan perekat (kekuatan ikatan antara partikel atau tekanan pada ikatan perekat). Pengembangan tebal maksimal adalah $12 \%$, sehingga dapat dilihat bahwa kayu lapis pada 4 merek dagang di pasaran Bengkalis cocok untuk digunakan di ekterior.

\section{KESIMPULAN DAN SARAN}

\section{Simpulan}

Adapun simpulan dari penelitian ini adalah :

1. Ada 4 Jenis kayu lapis yang beredar di pasaran Kota Bengkalis dengan ketebalan \pm 3 $\mathrm{mm}$.

2. Lapisan muka, dalam dan belakang yang memiliki kualitas yang baik (mutu A)sesuai dengan SNI 01-5008.2-1999 dengan merek dagang OFR.

3. Kadar Air kayu lapis dari semua merek dagang hanya fortune dan OFR sudah sesuai dengan SNI 01-5008.2-1999.

4. Kayu lapis dengan 4 merek dagang dapat digunakan diluar ruangan akan tetapi tidak cocok untuk bahan baku kontruksi structural hanya coock jadi bahan baku pembuatan furniture dilihat dari kualitas lapisan muka, dalam dan belakang.

\section{Saran}

Dilakukan penelitian lanjutan mengenai ketahanan kayu lapis terhadap organisme perusak (rayap, jamur dan marine borere).

\section{DAFTAR PUSTAKA}

Baldwin, R.F. 1995. Plywood and Venner-Based Products : Manufacturing Practices. Miller Freeman Books. USA.

Departemen Kehutanan RI. 2005. Statistik Kehutanan. Jakarta.

Haygreen, J.G., and JL.Bowyer.1993. Hasil Hutan dan IImu Kayu (Suatu 
Pengantar).Diterjemahkan oleh Sutjipto A. Hadikusumo.Gadjah Mada University

Press.Yogyakarta.

Iswanto, A.H. 2008. Kayu Lapis. Karya Tulis. Departemen Kehutanan. Fakultas Pertanian. Universitas Sumatera Utara.

Massijaya, M.Y. 2006. Plywood.Bahan Kuliah IImu dan Teknologi Kayu. Program Studi IImu Pengetahuan Kehutanan, Sekolah Pascasarjana IPB. Bogor

SNI 01-5008.2-1999 tentang Kayu Lapis Dan Papan Blok Penggunaan Umum.

Syamani. F.A., Prasetyo. K.W., Budiman. I.,Subyakto dan Subiyanto. B. 2008. Sifat Fisis MEkanis Papan Partikel dari Serat Sisal atau Serat Abaka Setelah Perlakuan Uap.J. Tropocal Wood Science and Technology Vol. 6.No. 2. 2008

Tsoumis, G. 1991. Science and Technology of Wood: Structure, Properties, Utilization. Van Nostrand Reinhold. New York

Youngquist. 1999. Wood Based Comptosites and Panel Product. Wood Hand Book: Wood as an Engineering Material. USA. 